\title{
Selection of Pinus spp. in South Africa for tolerance to infection by the pitch canker fungus
}

\author{
R.G. Mitchell ${ }^{1}$, M.J. Wingfield ${ }^{2}$, GR Hodge ${ }^{3}$, E.T. Steenkamp ${ }^{2}$ and T.A. Coutinho ${ }^{2}$ \\ ${ }^{1}$ York Timbers, Sabie, South Africa \\ ${ }^{2}$ Forests and Agricultural Biotechnology Institute, University of Pretoria, South Africa \\ ${ }^{3}$ Camcore, North Carolina State University, USA \\ Corresponding authorgmitchell@york.co.za
}

\begin{abstract}
The increasing threats from pests and diseases demand that the South African forest industry explores options to deploy alternative pine species in plantation development. This is especially true for species, such as Pinus patula Schiede \& Deppe ex Schltdl. \& Cham., which are highly susceptible to the pitch canker fungus Fusarium circinatum. Losses due to F. circinatum have been confined mostly to nurseries and at field establishment resulting in a significant cost to the industry. Although the fungus has not as yet resulted in stem and branch infections on established $P$. patula in South Africa, it has caused pitch canker on other, more susceptible species such as P. radiata D. Don., and P. greggii Engelm. ex Parl. As alternatives to P. patula on the warmer and cooler sites in South Africa, families of $P$. elliottii Engelm var. elliottii, $P$. tecunumanii (Schw.) Eguiluz \& Perry, P. maximinoi H.E. Moore and P. pseudostrobus Lindl. were screened for tolerance to infection by F. circinatum in greenhouse studies. Seedlings were wounded and inoculated with spores of $F$. circinatum. Lesion development following inoculation was used to differentiate the levels of tolerance between families. The results showed that $P$. maximinoi, $P$. pseudostrobus, and the low elevation variety of $P$. tecunumanii are highly tolerant to infection with very little family variation. The narrow sense heritability estimates for these species were less than 0.06 . In contrast, $P$. elliottii showed good tolerance with some family variation and a heritability of 0.22 , while the high elevation source of $P$. tecunumanii showed a high degree of family variation and a heritability of 0.59 . These results provide the industry with
\end{abstract}


valuable information on pine species tolerant to $F$. circinatum that could be used as alternatives to P. patula in South Africa.

Keywords; CAMCORE, tree disease, screening for resistance, disease avoidance, plantation forestry

\section{Introduction}

Pitch canker is a serious disease of pines caused by the fungus Fusarium circinatum (anamorph) that has a sexual state (teleomorph) known as Gibberella circinata (Nierenberg and O'Donnell 1998; Britz et al. 2005). Although the exact origin of pitch canker is unknown, studies indicate that the pathogen may be endemic to Mexico (Guerra-Santos 1999), southeast USA (Wikler and Gordon 2000) or as far south as Central America (Dvorak et al., 2009). The first discovery of the disease in South Africa was 1991 (Viljoen et al. 1994) suggesting that F. circinatum is an introduced pathogen into this country (Wikler and Gordon, 2000). From vegetative compatibility group, and allelic frequency studies, the South African population has the third highest degree of genetic diversity after Mexico and the south-eastern USA (Viljoen et al. 1997; Wikler and Gordon 2000; Britz et al. 2005). Accepting that the South African population is in all probability young, several possibilities for its diversity have been suggested. Many genotypes could have been initially introduced (Viljoen et al. 1997), subsequent introductions have occurred (Britz et al. 2005) or sexual reproduction is occurring (Viljoen et al. 1997).

Pitch canker can result in branch die-back, stem cankers and in large-scale mortality (Dwinell and Phelps 1977; Bethune and Hepting 1963; Storer et al. 1999). Consequently, F. circinatum is considered one of the most serious pathogens threatening plantations of non-native Pinus spp. worldwide (Wingfield et al. 2008). The susceptibility of Pinus spp. to F. circinatum, however, varies considerably. Thus, some species, such as Pinus radiata and the northern provenances of $P$. greggii are highly susceptible whilst other species including $P$. jaliscana and $P$. oocarpa display high levels of tolerance to infection (Hodge and Dvorak 2000). This indicates that the threat of $F$. circinatum can be reduced by planting more tolerant species in high risk areas. 
In South Africa, P. patula is the most important softwood planted (Department of Agriculture, Forestry and Fisheries 2008) and was the first pine species to be associated with the pitch canker fungus (Viljoen et al. 1994). The disease has now spread to most pine growing nurseries in the country where it is managed with varying degrees of success. The most significant effect of $F$. circinatum on P. patula, however, can be seen on young seedlings that become infected and die after establishment (Crous 2005; Mitchell et al. 2011). More recently, pitch canker was discovered on mature $P$. radiata and $P$. greggii trees in the Southern and Eastern Cape provinces of South Africa (Coutinho et al. 2007; Roux 2007). Given the speed at which the nursery disease has progressed since it was first identified, and the current situation with growing areas of mature trees being infected, it seems reasonable to expect that pitch canker may spread to other areas and species, which could include mature $P$. patula trees.

In the long term, tree breeders in South Africa hope that the tolerance of P. patula to $F$. circinatum could be improved by including tolerance as a selection criterion in their breeding programmes (Mitchell et al. 2011). In the shorter term the tolerance of $P$. patula can be improved through hybridization with more tolerant species. The simplest immediate solution, however, is to deploy alternative species that are known to be tolerant to infection by F. circinatum, at least in high-risk sites (Mitchell et al. 2011).

South Africa is fortunate to have a wide range of site types that are suited to a number of Pinus species (Morris and Pallett 2000). Although P. patula is planted across many of these sites, $P$. elliottii and $P$. taeda have been planted in increasing numbers in the last decade as substitutes due to their tolerance to F. circinatum (Hodge and Dvorak 2000). In South Africa, P. taeda is considered highly tolerant to F. circinatum (Hodge and Dvorak 2000; Roux et al. 2007). However, due to its specific site requirements (well drained soils that are a minimum of $750 \mathrm{~mm}$ deep, in areas that receive a minimum of $950 \mathrm{~mm}$ of rain per year, and on sites below $1400 \mathrm{~m}$ (Schönau and Grey 1987; Morris and Pallett 2000; Zwolinski and Hinze 2000), few areas are suitable for this species. This, together with its tolerance to $F$. circinatum, makes it less important to screen the local population of $P$. taeda. 
Pinus elliottii is less tolerant to F. circinatum than P. taeda (Hodge and Dvorak 2000) and is South Africa's second most important pine crop (Department of Agriculture, Forestry and Fisheries 2008). Elsewhere, large variation in tolerance to $F$. circinatum has been found between P. elliottii families, which have enabled breeders to improve the overall tolerance of the species (Rockwood et al. 1988; Blakeslee and Rockwood 1999). This suggests that it would be important to screen the South African P. elliottii selections for tolerance to $F$. circinatum.

There are a number of other Pinus species that show potentially high levels of tolerance to $F$. circinatum in research trials and in commercial plantings. On warmer sites, $P$. tecunumanii and P. maximinoi are the most promising (Kietzka 1988; Dvorak et al. 2000, 2002; Galpare et al. 2001). Fewer species are available on the temperate and cooler sites that perform as well as $P$. patula. Similar performance can be achieved from the Mexican pine, P. greggii, on cold and dry regions in South Africa (Dvorak et al. 1996) but the susceptibility of the species to F. circinatum (Hodge and Dvorak 2000) does not make it a suitable alternative to reduce the risk of pitch canker. Pinus pseudostrobus, however, has also shown potential in these regions (Coetzee 1985) and is tolerant to $F$. circinatum (Hodge and Dvorak 2000). It is already being deployed commercially by one company. Although P. tecunumanii, P. maximinoi and P. pseudostrobus are known for their higher levels of tolerance to $F$. circinatum than $P$. patula, little is known about the degree of within family variation to infection by the pathogen.

In this study, families of P. maximinoi, P. pseudostrobus, P. tecunumanii and P. elliottii, were screened for their tolerance to $F$. circinatum. This was achieved using greenhouse inoculations. The objectives of the study were to determine whether meaningful family variation, in tolerance to $F$. circinatum, exists in these species which would indicate that their general tolerance could be further improved though breeding and selection. 


\section{Materials and Methods}

\section{Plant material}

A number of Camcore trials were planted in the early 1980's testing the performance of unimproved $P$. tecunumanii and $P$. maximinoi families from various provenances (localities) in Mexico and Central America. Camcore is an international tree conservation and domestication programme at North Carolina State University, USA. The organization is actively involved in the collection of wild populations of pine species for conservation and domestication in areas outside of their natural distribution. The trials were situated on Komatiland Forests' property, South Africa. The seed of these two species, collected for this study, was harvested from trees that had been selected for superior growth and stem form based on their breeding values in the Camcore trials. In the original field design, families were grouped by provenance and, therefore, the selections were likely to be pollinated by surrounding trees of the same provenance. However, there would also be some natural cross pollination between trees of different provenances. This is relevant because the seed collected would not necessarily represent a pure provenance.

\section{Pinus tecunumanii}

The P. tecunumanii seed was harvested, in 2004 and 2005, from 73 selected trees, representing 12 provenances in the Camcore trials (Table 1). Of the 73 trees, 49 were sampled from 4 provenances that occur below 1500 meters above sea level (low elevation or LE) in Honduras. The other 24 selections represented 8 provenances above this altitude (high elevation or HE). With the exception of one high elevation provenance (Las Trancas), which is found in Honduras, all others originate in Mexico and Guatemala.

The P. tecunumanii seed was sown in September 2006 in preparation for inoculating the seedlings in April 2007 (Table 2). When the seedlings were 6-months-old, they were arranged in a randomised complete block design with 4 replications. Based on seedling availability, each treatment was represented by approximately 88 seedlings or 22 seedlings per plot. Seedlings of P. patula and $P$. elliottii, from a commercial seed orchard, were included as controls in the trial. 


\section{Pinus maximinoi}

The P. maximinoi seed was harvested, in 2005 and 2006, from 105 selected trees representing 13 provenances across Mexico, Guatemala and Honduras (Table 1). In this collection, most provenances were represented by 4 to 13 trees. The seed was sown in July 2007 in preparation for the March 2008 inoculation. When the seedlings were 7-months-old, they were packed out in a randomised complete block design with 4 replications. Based on seedling availability, each treatment was represented by approximately 56 seedlings. Seedlings of $P$. tecunumanii HE, $P$. tecunumanii LE, P. taeda, P. elliottii and P. patula were included in the trial as controls (Table 2).

\section{Pinus elliottii}

Seed, from a total of 49 open pollinated $2^{\text {nd }}$ generation $P$. elliottii families, was provided by Komatiland Forests from their breeding programme for this trial. Seed from the highly susceptible $P$. elliottii clone FA2 (Hodge and Dvorak 2000, 2007) was provided by Camcore and included in the study. All seed was sown in March 2009 in preparation for screening the seedlings in December 2010. When the seedlings were 8-months-old, they were arranged in a randomised complete block design with 4 replications. Based on seedling availability, each treatment was represented by approximately 44 seedlings. Commercial open pollinated seedlings of P. patula, P. elliottii and P. taeda were included as controls (Table 2).

\section{Pinus pseudostrobus}

Seed of 33 selected $P$. pseudostrobus trees, in a commercial stand, was supplied by Komatiland Forests for this trial. The seed was sown in May 2009 in preparation for screening the seedlings in December 2010, together with the P. elliottii trial. When the seedlings were 7-months-old, they were arranged in a randomised complete block design with 4 replications. Based on seedling availability, each treatment was represented by approximately 80 seedlings. As with the P. elliottii trial, open pollinated seed of P. elliottii, P. taeda and P. patula was included as controls (Table 2).

The seedlings in all the trials were raised in the Komatiland Forest's Research nursery at Sabie, South Africa ( $\left.\mathrm{S} 25^{\circ} 03.22^{\prime}, \mathrm{E} 30^{\circ} 46.859^{\prime}\right)$. The local climate can be described as warm temperate 
with a mean annual temperature of $15^{\circ} \mathrm{C}$ and approximately $1300 \mathrm{~mm}$ of rain predominantly during the summer months. Seedlings were raised in composted pine bark in the Unigro tray, consisting of loose inserts, under plastic covering. Each individual insert is square in shape with a top end width of $37 \mathrm{~mm}$, length of $100 \mathrm{~mm}$, and volume of $90 \mathrm{ml}$. The side walls have pronounced internal ridges to prevent root spiraling. Granular fertilizer (2:3:2 (N:P:K)) was applied as needed. No fungicides were applied to the seedlings during their establishment. Due to the different seed collection dates the trials were raised at different times in the nursery.

\section{Inoculation procedures}

The seedlings, for each trial, were transported to a greenhouse at the University of Pretoria, specifically erected for the purpose of screening pine families for tolerance to F. circinatum, on different occasions (Table 2). The greenhouse had a wet-wall cooling system and a separate heating system to maintain air temperatures of approximately $25^{\circ} \mathrm{C}$. The plants were left to acclimatise for $1-4$ weeks before the seedlings were inoculated.

The inoculum was prepared on the same day that the seedlings were inoculated, using a equal mixture of conidia from three highly virulent South African isolates (CMW 3577, 3578, and 3579) of $F$. circinatum that are maintained by the Tree Protection Co-operative Programme (TPCP) in the culture collection of the Forestry and Agricultural Biotechnology Institute (FABI), University of Pretoria. The isolates were cultured on half strength Potato Dextrose Agar (PDA; $2 \mathrm{~g}$ potato extract, $10 \mathrm{~g}$ dextrose, and $7.5 \mathrm{~g}$ agar/l distilled water) under sterile conditions for 7 days at $25^{\circ} \mathrm{C}$ prior to inoculation. Cultures were flooded with sterile water containing $15 \%$ glycerol and spores were dislodged using a glass "hockey stick". The spore concentration was determined using a haemocytometer, viewed under a light microscope at 20x magnification, and adjusted to 50000 spores $/ \mathrm{ml}$. The tubes of inoculum were maintained on crushed ice prior to inoculation.

In the greenhouse, the apical bud of each seedling was removed using sharp secateurs, and a 10 $\mu 1$ inoculum (500 spores per infection site) was immediately applied to the wounded tip using a 
micro-pipette. Once inoculated, plants in the trial were watered daily and assessed for lesion development 8-weeks after inoculation. The lengths of lesions were measured from the tips of the seedlings, at the point of inoculation, to the point where the tissue showed no visible necrosis. The seedling height, from the root collar to the wounded tip, was also measured. For each inoculated seedling the proportion of lesion length to the length of the seedling at the time of inoculation was expressed as a percentage of die-back. In many seedlings, new shoots (resprouts) had formed below the lesions and the length of these was measured. All measurements were recorded in millimetres $(\mathrm{mm})$.

\section{Statistical Analyses}

The statistical package SAS version 9.1.3 (SAS Institute, 2003) was used to carry out the data analysis. An analysis of variance (ANOVA) was conducted on the data (seedling height, percentage die-back, lesion length, and length of the re-sprout) for each of the four inoculation trials. In order to correct for the influence that the seedling size could have had on the variables, initial height was analysed as a covariate (Hodge and Dvorak 2000). A Pearson correlation coefficient analysis was carried out to determine the relationship that these variables had on each other. As the trials were analysed on separate occasions, different tests were used to determine treatment differences. A t-test was used to compare differences between provenance and species means in the P. tecunumanii data-set and a Student Newman Keuls (SNK) test was used to test for differences between family means. A Duncan Multiple Range test was used to determine treatment differences in the P. maximinoi, P. elliottii and P. pseudostrobus datasets. Narrow sense heritability was estimated following the method described by Dieters et al. (1995) for open-pollinated families $\left(h^{2}=\left(3 \times \sigma_{\text {female }}^{2}\right) / \sigma_{\text {phenotypic }}^{2}\right)$.

\section{Results}

After inoculation, lesions were observed in P. patula control seedlings within 7 days. Shortly thereafter, the $P$. tecunumanii (HE) treatments developed lesions followed by lesions in $P$. 
elliottii, families of $P$. tecunumanii (LE), P. maximinoi and P. pseudostrobus. Sprouts were seen developing below the lesion on those species that took longer to develop lesions. Previous studies have shown that lesion length and the percentage dieback can be influenced by the height of the seedling (Hodge and Dvorak 2000) or the diameter of an infected branch in field studies (Roux et al. 2007). In these cases taller seedlings, or thicker branches, reduced lesion development. It has also been found that lesion length and percentage dieback correlate well (Hodge and Dvorak 2000). However, it has not been reported that the ability of the seedling to produce sprouts, below the lesion, may be related to the tolerance of the seedling.

\section{Pinus tecunumanii}

The effect of seedling height influenced percent die-back and the length of re-sprout significantly $(p<0.0001)$, except for lesion length at the family level. The Pearson Correlation Coefficients between means at the provenance and family level indicate highly significant relationships for all comparisons. For provenance, the relationship between lesion length and percentage dieback was the strongest $(\mathrm{r}=0.99)$ and lesion length was used to rank treatments. The correlation between lesion length and the degree of re-sprout was strongly negative at the provenance $(\mathrm{r}=-0.78)$ and family $(r=-0.76)$ levels, indicating that treatments with longer lesions produced shorter sprouts.

In this part of the study $P$. tecunumanii (LE) displayed the greatest level of tolerance to infection with a mean lesion length of $2.78 \mathrm{~mm}$ (Table 3 ). This did not differ significantly from the lesion lengths obtained for $P$. elliottii $(3.11 \mathrm{~mm})$. In contrast, $P$. tecunumanii (HE) had an average lesion length of $9.61 \mathrm{~mm}$. This was significantly greater than lesions on P. tecunumanii (LE) and the P. elliottii control, but not as long as those on P. patula $(22 \mathrm{~mm})$ (Table 3). When assessing provenance variation, there were no differences in lesion lengths between the four low elevation provenances, while there were large differences among the high elevation provenances (Table 4). The high elevation provenance from Honduras, Las Trancas, was the most tolerant of this variety and similar in tolerance to the other P. tecunumanii (LE) provenances from Honduras (Table 4). There were also no significant differences in lesion lengths between the 49 low elevation families screened (SNK grouping not shown) and all low elevation families were 
similar to the P. elliottii control (Fig. 1). On the other hand, large family variation in lesion lengths occurred in the high elevation source (Fig. 1).

\section{Pinus maximinoi}

The effect of seedling height, at the time of inoculation, influenced percentage die-back moderately $(\mathrm{r}=-0.22)$ and had a weak, but significant, effect on the length of the re-sprout $(\mathrm{r}=-$ 0.12). Seedling height had no effect on lesion length. The relationship between lesion length and percent die-back was extremely strong $(\mathrm{r}=0.92)$ and lesion length was used to rank treatments. The overall mean lesion length of $P$. maximinoi $(3.19 \mathrm{~mm})$ was no different to that on $P$. tecunumanii (LE) $(2.69 \mathrm{~mm}$ ) (Table 5). Both of these species also showed the greatest ability to re-sprout. $P$. maximinoi $(3.19 \mathrm{~mm})$ was significantly more tolerant than $P$. taeda $(4.95 \mathrm{~mm}), P$. elliottii $(5.91 \mathrm{~mm})$, as well as $P$. tecunumanii $(\mathrm{HE})(8.63 \mathrm{~mm})$. The $P$. patula seed orchard control was more susceptible than all other treatments with an average lesion length of $21.04 \mathrm{~mm}$ (Table 5).

In this part of the study there was little variation between provenances (Table 6), or families (Fig. 2), of P. maximinoi in lesion length with only those at the extreme range of infection differing significantly (Duncan grouping not shown). In this comparison, provenances represented by fewer than 4 families, were excluded. The lack of family variation corresponded to a very low narrow-sense heritability estimate $\left(\mathrm{h}^{2}=0.014\right)$ for lesion length.

\section{Pinus elliottii}

The effect of seedling height influenced percent die-back caused by $F$. circinatum $(\mathrm{p}<0.001)$. Similar to the other studies, lesion length and percent dieback were strongly related $(\mathrm{r}=0.94)$ and lesion length was again used to rank treatments. Lesion length had a weak, but significant, relationship with the ability for the families to re-sprout $(r=-0.28)$ indicating that families with shorter lesions produced longer shoots. Overall, $P$. elliottii produced the longest shoots followed by $P$. patula then $P$. taeda. 
Pinus taeda ranked the most tolerant to $F$. circinatum with a mean lesion length of $4.2 \mathrm{~mm}$ (Table 7). Statistically, the lesion lengths were no different to the overall mean lesion length of P. elliottii $(5.73 \mathrm{~mm})$. However, $P$. taeda was more tolerant than $P$. elliottii when comparing percentage die-back. P. patula was the most susceptible with a mean lesion length of $23.7 \mathrm{~mm}$ (Table 7). Family variation, among $P$. elliottii, was greater than in $P$. maximinoi and $P$. tecunumanii (LE) (Fig. 3). Most families ranked more susceptible than P. taeda. However, there were also a number of families that ranked more tolerant than $P$. taeda. The $P$. elliottii family FA2, previously used as a susceptible control by Hodge and Dvorak (2000, 2007), ranked as the $6^{\text {th }}$ most susceptible in this study (Fig. 3). Narrow sense heritability was estimated at 0.22 .

\section{Pinus pseudostrobus}

As with all the other trials, seedling height at the time of inoculation with $F$. circinatum influenced the percentage dieback. In this case, lesion development was also influenced by seedling height. Neither lesion length, nor the percentage die-back, influenced the ability of plants to re-sprout. Similar to all the other trials, lesion length and percentage dieback were strongly correlated $(r=0.99)$ and lesion length was used to rank the families.

Compared to the controls, $P$. pseudostrobus was the most tolerant to $F$. circinatum with a mean lesion length of $3.7 \mathrm{~mm}$ followed by P. taeda $(7.1 \mathrm{~mm})$, P. elliottii $(10.8 \mathrm{~mm})$ and P. patula (24.6 mm) (Table 8). Family variation was low with 32 of the 33 P. pseudostrobus families ranked more tolerant than $P$. taeda (Fig. 4). Heritability was estimated at 0.06 .

\section{Discussion}

The results of this study clearly show that the risk that $F$. circinatum poses to young and mature stands of $P$. patula in South Africa could be largely overcome by planting alternative species. Pinus tecunumanii (HE), suitable to warm-temperate and sub-temperate sites, showed the 
greatest variation in tolerance, where many families ranked more susceptible than P. patula. This indicates that screening families of this variety is strongly recommended before selecting those for deployment. This is particularly important if families of $P$. tecunumanii (HE) are used as hybrid partners with P. patula. Pinus pseudostrobus, a species that could be significantly improved in growth through breeding, showed considerable tolerance to $F$. circinatum in this study. This species could, therefore, become an important alternative on the temperate sites of South Africa in the future. P. maximinoi, and P. tecunumanii (LE), showed excellent tolerance to $F$. circinatum with little family variation indicating that these could be planted on the warmer sites, without concern that they may become infected with F. circinatum. Pinus elliottii, a highly adaptable species suitable to a wide range of sites, showed sufficient variation in tolerance to suggest that screening families and selecting those with high levels of tolerance to infection by $F$. circinatum should be considered when deploying this species.

\section{Pinus tecunumanii}

The differences seen at the ecotype level where $P$. tecunumanii (LE) was significantly more tolerant to $F$. circinatum than $P$. tecunumanii $(\mathrm{HE})$ has been previously reported (Hodge and Dvorak, 2000). In this study the mean lesion length of $P$. tecunumanii (HE) was longer than $P$. elliottii which is opposite to that reported by Hodge and Dvorak (2000). Although the tolerance of $P$. tecunumanii (LE) was similar to the mean of $P$. elliottii, where large family variation could be seen (Fig. 3), neither provenance nor family differences existed. This illustrates the high level of tolerance of this source. This was further demonstrated by the strong tendency to re-sprout after inoculation. The variation in tolerance of various $P$. tecunumanii $(\mathrm{HE})$ provenances to $F$. circinatum has also been reported elsewhere (Hodge and Dvorak, 2007).

The very large variation in tolerance of the $24 P$. tecunumanii (HE) families proved to be strongly heritable $\left(\mathrm{h}^{2}=0.59\right)$. A similar heritability estimate $\left(\mathrm{h}^{2}=0.58\right)$ was calculated for $14 P$. tecunumanii (HE) families collected from a seed orchard in Colombia (Isaza 2008). Although a few $P$. tecunumanii (HE) families in this study were more susceptible than the $P$. patula control (Fig. 1), the overall mean for this variety indicated much higher levels of tolerance than $P$. 
patula. Furthermore, the high level of heritability indicates that the tolerance of $P$. tecunumanii (HE) could be improved upon relatively easily. It also suggests that families of $P$. tecunumanii (HE) should be screened for susceptibility before deployment, while those from the low elevation ecotype need not be screened. The high degree of provenance variation in the high elevation ecotype, compared to the lack of variation in the low elevation ecotype, has also been reported for traits other than susceptibility to infection by $F$. circinatum. For example, Malan (1994) found marked differences in mean inter-node length, branch diameter, and air-dried wood density between different high elevation provenances whilst no significant variation could be found for these traits amongst low elevation provenances.

In recent years tree breeders have learnt that $P$. tecunumanii hybridizes easily with $P$. patula and that the hybrid can outperform P. patula in field trials (Nel et al. 2006). Field inoculation studies on 3-year-old trees have shown that the tolerance of this hybrid to $F$. circinatum is superior to that of $P$. patula (Roux et al. 2007). The higher level of tolerance to $F$. circinatum is clearly seen by improved survival of the hybrid over P. patula in areas of little or no frost (Mitchell, unpublished). However, the results of this study suggest that not all of the hybrids made with families of the high elevation variety will be more tolerant to $F$. circinatum. Therefore, due to the susceptibility to frost, particularly in the low elevation ecotype (Dvorak et al. 2000), as well as susceptibility to F. circinatum in the high elevation ecotype (Hodge et al. 2000), care should be taken when planting this hybrid on a large scale without prior selection.

\section{Pinus maximinoi}

Kietzka (1988) recommended planting P. maximinoi in South Africa in order to broaden the species base planted "should one of our major pine species (P. patula, P. elliottii, and P. taeda) become subject to major pest or disease problems". Although the tolerance of $P$. maximinoi to $F$. circinatum was probably unknown at the time, it was later established that it is more tolerant than P. patula (Hodge and Dvorak 2000). 
The main constraints to planting $P$. maximino $i$ are its susceptibility to frost during establishment (Dvorak et al. 2000) and the production of heavy branch whorls that reduce sawn board timber quality (Malan 2006). However, saw millers are now able to remove the knot clusters to produce long lengths of clear timber (Malan 2006). Although $P$. maximinoi is sensitive to frost, which can result in establishment failure, it often survives better than $P$. patula. In a number of Camcore trials planted during 2008, the survival of $P$. maximinoi was consistently better than $P$. patula with an average survival across all trials of $96 \%$ compared with $80 \%$ for $P$. patula (data not shown). This indicates that many of the warmer and wetter sites currently planted to P. patula, could be replaced with $P$. maximinoi. These would include areas between 15 and $17^{\circ} \mathrm{C}$ mean annual temperature with $>1000 \mathrm{~mm}$ mean annual rainfall. This constitutes approximately $11 \%$ of the summer rainfall regions of South Africa where P. patula would be planted (Mitchell unpublished).

\section{Pinus elliottii}

Due to the greater tolerance to $F$. circinatum, $P$. elliottii survives well after planting, making it a popular species among foresters. However, the general tolerance of this species may not be sufficient to eliminate the risk of a pitch canker outbreak in South Africa. In the southern USA, mortality of infected P. elliottii stands has reached levels of $25 \%$ with as much as $98 \%$ of all trees showing infection (Blakeslee and Oak 1980). Fortunately, large genetic variation in tolerance to $F$. circinatum exists in the species, which has allowed breeders to identify and select tolerant individuals (Rockwood et al. 1988). Blakeslee and Rockwood (1999) reported narrowsense heritability estimates around 0.25 in both greenhouse and field studies, similar to the $\mathrm{h}^{2}=0.22$ estimated in this study, so genetic improvement of resistance within P. elliottii is certainly possible. This was supported by the fact that the susceptible family (FA2), used in the studies by Hodge and Dvorak $(2000,2007)$, ranked as the $6^{\text {th }}$ most susceptible treatment in the present trial. Using family FA2 as a benchmark, several families were equally susceptible in this sample, highlighting the importance of screening P. elliottii in South Africa. Although the $P$.

elliottii commercial seed orchard seedlot was more tolerant than family FA2, a number of families ranked more tolerant than the commercial P. elliottii seedlot and also P. taeda (Fig. 3). 
Due to the adaptability of $P$. elliottii to a wide range of sites in South Africa, the species will continue to be planted on a large scale until alternative species and hybrids are deployed in greater numbers. The species has been planted in all areas where P. patula has been planted including sub-tropical sites not suited to P. patula. However, the growth of the species is inferior to that of $P$. patula on most sites, particularly those in temperate regions (Darrow and Coetzee 1983; Morris and Pallet 2000). Relative to alternative species, such as $P$. tecunumanii and $P$. maximinoi, the easy accessibility of seed makes $P$. elliottii an attractive alternative to $P$. patula. However, it should be cautioned that the slower growth of P. elliottii compared to P. patula (Morris and Pallett 2000) could cost more than the cost that $F$. circinatum might cause to $P$. patula (Mitchell et al. 2011).

\section{Pinus pseudostrobus}

Currently, few other species, suited to the cold regions of South Africa, grow as well as P. patula (Darrow and Coetzee 1983; Coetzee 1985; Morris and Pallett 2000). The limited choice is particularly challenging for breeders as the majority of South Africa's afforested regions experience mild to severe frost in the winter months. Of all the Mexican and Central American pines suited to colder regions, $P$. pseudostrobus shows the greatest tolerance to $F$. circinatum (Hodge and Dvorak 2000).

Hodge and Dvorak (2000) found that P. pseudostrobus was moderately resistant to infection by $F$. circinatum, where it was more tolerant than $P$. elliottii, somewhat less tolerant than the high elevation variety of $P$. tecunumanii and significantly less tolerant than $P$. taeda. The $P$. pseudostrobus seed used in the present study came from selections in a commercial stand with good growth such as described by Coetzee (1985). Little is known regarding the origin of these selections, however, in this study most families ranked more tolerant than P. taeda. One possible explanation is related to seedling size at the time of inoculation. In the Hodge and Dvorak (2000) study, the $P$. pseudostrobus seedlings were much smaller than most of the other species and the covariate adjustment for height may have not been sufficient to correct for this factor and to 
properly compare the tolerance of $P$. pseudostrobus. In contrast, in the present study, the $P$. pseudostrobus seedlings were of very similar height to the P. taeda, P. elliottii and P. patula controls.

\section{Conclusion}

In this study, the subtropical species, $P$. tecunumanii (LE) and $P$. maximinoi, were highly tolerant to infection by $F$. circinatum with little meaningful family variation. This suggests that they could be deployed with little concern of infection by the pathogen. Due to their susceptibility to frost, these species will be limited to the warmest areas where P. patula is currently planted. The sub-tropical to warm temperate species, P. elliottii, was less tolerant than $P$. tecunumanii (LE) and P. maximinoi, and displayed sufficient family variation with strong heritability. This result suggests that $P$. elliottii families should be screened and selected for tolerance to $F$. circinatum prior to decisions being made for large scale deployment. This species is highly adaptable and probably the most suitable alternative to $P$. patula for planting on warm temperate sites. The warm to sub-temperate species $P$. tecunumanii (HE) was less tolerant to infection $F$. circinatum than $P$. elliottii and displayed very large family variation with extremely high heritability. This indicates that it should be screened for tolerance to F. circinatum prior to deployment. Disease screening will be especially important where P. tecunumanii is considered for hybridization with $P$. patula. In contrast, the cold temperate species, P. pseudostrobus, showed extreme tolerance to $F$. circinatum with little to no family variation. Through further breeding and selection for growth and other good characteristics, this species may become an alternative to $P$. patula on cold sites.

Overall results of this study have shown that there is good opportunity to develop alternative species to $P$. patula in areas where the pitch canker fungus limits the successful production of this species. The results are generally consistent with those from prior studies, field observations and prior studies where established trees have been used in inoculations (Roux et al. 2007). It is, however, important to recognise that this study was based on seedling evaluations, which clearly provide an indication of resistance to $F$. circinatum, but may not fully encompass the field situation. It is well-known that trees respond differently to infection by pathogens at different 
stages of development and field experiments extending the limits of this study need to be conducted.

\section{Acknowledgements}

We thank Komatiland Forests for providing the seed and incurring the costs involved in raising and screening the plant material. We also acknowledge the assistance of Bernice Porter who cared for the plants and coordinated the screening activities at the University of Pretoria. Members of the Tree Protection Co-operative Programme (TPCP) and members of the Technology and Human Resources for Industry Programme (THRIP), an initiative of the Department of Trade and Industry (DTI), are thanked for financial support.

\section{References}

Bethune JE, Hepting GH (1963) Pitch canker damage to South Florida Slash pine Journal of Forestry 61: $517-522$.

Blakeslee GM, Oak SW (1980) Significant mortality associated with Pitch canker infection of Slash pine in Florida. Plant Disease 63: 1023 - 1025

Blakeslee GM, Rockwood D (1999) Variation in resistance to pitch canker in slash and loblolly pines. Current and Potential Impacts of the Pitch Canker in Radiata pine: in Devey ME, Matheson AC, Gordon, T. R. Proceedings of the IMPACT Montery Workshop, Montery, California. p. $70-75$.

Britz H, Coutinho TA, Wingfield BD, Marasas WFO, Wingfield MJ (2005) Diversity and differentiation in two populations of Gibberella circinata in South Africa. Plant Pathology 54: 46-52.

Coetzee H (1985) Provenance research on Mexican pines. Southern African Forestry Journal 135: 68-73

Coutinho TA, Steenkamp ET, Mongwaketsi K, Wilmot M, Wingfield MJ (2007) First outbreak of pitch canker in a South African pine plantation. Australasian Plant Pathology 36: 256 $-261$ 
Crous JW (2005) Post establishment survival of Pinus patula in Mpumalanga, one year after planting. Southern African Forestry Journal 205: 3 - 8

Darrow K, Coetzee H (1983) Potentially valuable Mexican pines in the summer rainfall region of Southern Africa. South African Forestry Journal 124 :23-35

Department of Agriculture, Forestry and Fisheries (DAFF) (2008) Report on commercial timber resources and primary roundwood processing in South Africa 2006/7. The Directorate, Forestry Technical and Information Services, Private Bag X93, Pretoria, 0001, South Africa.

Dieters M J, White TL, Hodge GR (1995) Genetic parameter estimates for volume from full-sib tests of slash pine (Pinus elliottii). Canadian Journal of Forest Research 25: 1397-1408

Dvorak WS, Gutiérrez EA, Galpare WJ, Hodge GR, Ororio LF, Bester C, Kikuti P (2000) Pinus maximinoi. In: Conservation \& Testing of Tropical \& Subtropical Forest Tree Species by the CAMCORE Cooperative, College of Natural Resources, NCSU, Raleigh, NC, USA. Pp $107-127$

Dvorak WS, Hamrick JL, Furman BJ, Hodge GR, Jordan AP (2002) Conservation strategies for Pinus maximinoi based on provenance, RAPD and allozyme information. Forest Genetics 9: $263-274$.

Dvorak WS, Kietzka JE, Donahue JK (1996) Three year survival and growth of provenances of Pinus greggii in the tropics and subtropics. Forest Ecology and Management 83: 123131

Dvorak WS, Potter KM, Hipkins VD, Hodge GR (2009) Genetic diversity and gene exchange in Pinus oocarpa, a Mesoamerican pine with resistance to the pitch canker fungus (Fusarium circinatum) International Journal of Plant Sciences 170: 609-626.

Dwinell LD, Phelps WR (1977) Pitch canker of Slash pine in Florida. Journal of Forestry 75: 488-489.

Gapare WJ, Hodge GR, Dvorak WS (2001) Genetic parameters and provenance variation of Pinus maximinoi in Brazil, Colombia, and South Africa. Forest Genetics 8: 159-170

Guerra-Santos J (1999) Pitch canker in Monterey pine in Mexico. Current and Potential Impacts of the Pitch Canker in Radata pine: in Devey, M. E., Matheson, A.C. and Gordon, T. R. Proceedings of the IMPACT Montery Workshop, Montery, California. p. 58 - 61. 
Hodge GR, Dvorak WS (2000) Differential responses of Central American and Mexican pine species and Pinus radiata to infection by the pitch canker fungus. New Forests 19: 241258

Hodge GR, Dvorak WS (2007) Variation in pitch canker resistance among provenances of Pinus patula and Pinus tecunumanii from Mexico and Central America. New Forests 33:193 206

Isaza N (2008) Flower promotion in Pinus maximinoi and Pinus tecunumanii in a tropical environment and artificial screening of high-elevation P. tecunumanii for resistance to Fusarium circinatum. M.Sc. thesis, North Carolina State University, Raleigh, North Carolina

Kietza JE (1988) Pinus maximinoi: A promising species in South Africa. Southern African Forestry Journal 145: 33 - 38

Malan FS (2006) The wood properties and sawn-board quality of South African-grown Pinus maximinoi (HE Moore). Southern African Forestry Journal 208: 39 - 48

Mitchell RG, Steenkamp ET, Coutinho TA, Wingfield MJ (2011) The pitch canker fungus: implications for South African forestry. Southern Forests 73: 1-13.

Morris AR, Pallett R (2000) Site requirements and species matching: Pines. In: Owen D (ed) South African Forestry Handbook, South African Institute of Forestry, vol 1: pp 80-84.

Nel A, Kanzler A, Dvorak W (2006) Development of a commercial breeding program for Pinus tecunumanii in South Africa. In: Fikret Isik (ed) Proceedings of the IUFRO Division 2 Joint Conference: Low Input Breeding and Conservation of Forest Genetic Resources: Antalya, Turkey, 9-13 October 2006. pp 158-161

Nierenberg HI, O'Donnell (1998) New Fusarium species and combinations in the Gibberella fujukuroi species complex. Mycologia 90:434 - 458

Rockwood DL, Blakeslee GM, Lowerts GA, Underhill EM, Oak SW (1988) Genetic strategies for reducing pitch canker incidence in Slash pine. Southern Journal of Applied Forestry 12: $28-32$.

Roux J (2007) Further outbreaks of pitch canker in South Africa. http://www.fabinet.up.ac.za/tpcp/pitch_canker_mature_trees 
Roux J, Eisenberg B, Kanzler A, Nel A, Coetzee V, Kietzka E, Wingfield MJ (2007) Testing of selected South African Pinus hybrids and families for tolerance to the pitch canker pathogen, Fusarium circinatum. New Forests, 33: 109 - 123

SAS Institute (2003) Cary, North Carolina, 27513, USA.

Schönau APG, Grey DC (1987) Site requirements for exotic tree species. In Southern African Institute of Forestry, Forestry Handbook pp. 82-94.

Storer AJ, Bonello P, Gordon TR, Wood DL (1999) Evidence of resistance to the pitch canker pathogen (Fusarium circinatum) in native stands of Monterey pine (Pinus radiata). Forest Science 45: 500-505.

Viljoen A, Wingfield MJ, Marasas WFO (1994) First report of Fusarium subglutinans f. sp. pini on pine seedlings in South Africa. Plant Disease 78: 309 - 312.

Viljoen A, Wingfield MJ, Gordon TR, Marasas WFO (1997) Genotypic diversity in a South African population of the pitch canker fungus Fusarium subglutinans f.sp. pini. Plant Pathology 46: 590-593.

Wikler K, Gordon TR (2000) An initial assessment of genetic relationships among populations of Fusarium circinatum in different parts of the world. Canadian Journal of Botany 78: $709-717$.

Wingfield MJ, Hammerbacher A, Ganley RJ, Steenkamp ET, Gordon TR., Wingfield BD, Coutinho TA (2008) Pitch canker caused by Fusarium circinatum - a growing threat to pine plantations and forests worldwide. Australasian Plant Pathology 37: $319-334$.

Zwolinski JB and Hinze WHF (2000) Silviculture regimes: Pines. In: Owen D (ed) South African Forestry Handbook, South African Institute of Forestry, vol 1: pp 116-120. 
Table 1. Pinus tecunumanii and P. maximinoi provenances screened for tolerance to Fusarium circinatum.

\begin{tabular}{|c|c|c|c|c|c|c|}
\hline \multicolumn{4}{|c|}{ Pinus tecunumanii } & \multicolumn{3}{|c|}{ Pinus maximinoi } \\
\hline Ecotype & Country & Provenance & Families & Country & Provenance & Families \\
\hline High & Guatemala & KM 47 & 1 & Guatemala & Coban & 13 \\
\hline High & Guatemala & San Jerónimo & 5 & Guatemala & San Jerónimo Guatemala & 19 \\
\hline High & Guatemala & San Lorenzo & 1 & Guatemala & San Juan Sacateqequez & 18 \\
\hline High & Honduras & Las Trancas & 3 & Guatemala & San Lorenzo & 1 \\
\hline High & Mexico & Chempil & 8 & Honduras & Dulce Nombre de Copan & 8 \\
\hline High & Mexico & Jitotol & 3 & Honduras & El Portillo & 16 \\
\hline High & Mexico & Montebelo & 6 & Honduras & Marcala & 4 \\
\hline High & Mexico & Napite & 1 & Honduras & Tatumbla & 6 \\
\hline Low & Honduras & Jocón & 3 & Mexico & Altamirano & 4 \\
\hline Low & Honduras & San Esteban & 9 & Mexico & Coapilla & 1 \\
\hline Low & Honduras & San Francisco & 15 & Mexico & La Cañada & 1 \\
\hline \multirow[t]{3}{*}{ Low } & Honduras & Villa Santa & 22 & Mexico & Monte Cristo & 1 \\
\hline & & & & Mexico & San Jerónimo Chiapas & 13 \\
\hline & & & 77 & & & 105 \\
\hline
\end{tabular}


Table 2. Details of plant material, trial layout and dates for inoculation of seedlings inoculated with $F$. circinatum.

\begin{tabular}{|c|c|c|c|c|}
\hline & P. tecunumanii & P. maximinoi & P. elliottii & P. pseudostrobus \\
\hline Date sown & $09 / 2006$ & $07 / 2007$ & $03 / 2009$ & $05 / 2009$ \\
\hline Date inoculated & 03/04/07 & $19 / 03 / 08$ & $01 / 12 / 09$ & $01 / 12 / 09$ \\
\hline Date assessed & $30 / 05 / 07$ & $21 / 05 / 08$ & $04 / 02 / 10$ & $04 / 02 / 10$ \\
\hline Families tested & $49 \mathrm{LE}^{* *}$ and $24 \mathrm{HE}^{*}$ & 104 & 49 & 33 \\
\hline Mean plot size & 22 & 14 & 11 & 20 \\
\hline Replications & 4 & 4 & 4 & 4 \\
\hline $\begin{array}{l}\text { Mean plants per } \\
\text { treatment }\end{array}$ & 88 & 56 & 44 & 80 \\
\hline $\begin{array}{l}\text { Range of plants } \\
\text { per treatment }\end{array}$ & $58-96$ & $12-64$ & $20-64$ & $51-95$ \\
\hline \multirow[t]{5}{*}{ Controls } & P. elliottii & P. taeda & P. elliottii & P. elliottii \\
\hline & P. patula & P. elliottii & P. patula & P. patula \\
\hline & & P. patula & P. taeda & P. taeda \\
\hline & & P. tec $H^{*}$ & & \\
\hline & & P. tecL** & & \\
\hline
\end{tabular}

*P. tecunumanii (high elevation)

** P. tecunumanii (low elevation)

Table 3. Mean values of the variables measured for the species tested as controls, against $\boldsymbol{P}$. tecunumanii.

\begin{tabular}{l|cccc}
\hline Species & Height & \multicolumn{3}{|c}{ Variables measured } \\
\cline { 3 - 5 } & $(\mathrm{mm})$ & Lesion length $(\mathrm{mm})$ & Dieback (\%) & Re-sprout (mm) \\
P. patula & $136.67^{\mathrm{C}}$ & $22.00^{\mathrm{C}}$ & $16.89^{\mathrm{C}}$ & $2.49^{\mathrm{C}}$ \\
P. tec (high) & $124.24^{\mathrm{B}}$ & $9.61^{\mathrm{B}}$ & $8.20^{\mathrm{B}}$ & $9.11^{\mathrm{B}}$ \\
P. elliottii & $148.34^{\mathrm{A}}$ & $3.11^{\mathrm{A}}$ & $2.41^{\mathrm{A}}$ & $10.66^{\mathrm{B}}$ \\
P. tec (low) & $147.68^{\mathrm{A}}$ & $2.78^{\mathrm{A}}$ & $2.37^{\mathrm{A}}$ & $21.78^{\mathrm{A}}$ \\
\hline
\end{tabular}

Species that share the same letter (Duncan grouping) are not significantly different. 
Table 4. Mean values of the variables measured for the species tested as controls, and $\boldsymbol{P}$. tecunumanii provenances.

\begin{tabular}{l|llcccc}
\hline & & & & \multicolumn{3}{c}{ Variables measured } \\
\cline { 4 - 6 } Provenance & Ecotype & Country & Families & Lesion & Dieback & Re-sprout \\
P. patula & Control & & Mix & $22.01^{\mathrm{A}}$ & 16.89 & 2.48 \\
San Jerónimo & HE & Guatemala & 5 & $11.48^{\mathrm{B}}$ & 10.65 & 7.56 \\
Montebello & HE & Mexico & 6 & $10.88^{\mathrm{B}}$ & 9.19 & 9.31 \\
Chempil & HE & Mexico & 8 & $10.19^{\mathrm{B}}$ & 8.48 & 8.95 \\
Jitotol & HE & Mexico & 3 & $8.1^{\mathrm{C}}$ & 6.28 & 10.83 \\
Las Trancas & HE & Honduras & 3 & $5.72^{\mathrm{D}}$ & 4.76 & 8.99 \\
San Esteban & LE & Honduras & 9 & $3.1^{\mathrm{D}}$ & 2.68 & 21.42 \\
San Francisco & LE & Honduras & 15 & $2.79^{\mathrm{D}}$ & 2.41 & 20.87 \\
$P$. elliottii & Control & & Mix & $3.09^{\mathrm{D}}$ & 2.39 & 10.66 \\
Jocón & LE & Honduras & 3 & $2.73^{\mathrm{D}}$ & 2.25 & 22.79 \\
Villa Santa & LE & Honduras & 22 & $2.61^{\mathrm{D}}$ & 16.89 & 22.41 \\
\hline
\end{tabular}

Provenances that share the same letter (Duncan grouping) are not significantly different.

Table 5. Mean values of the variables measured for the species tested as controls, against $P$. maximinoi.

\begin{tabular}{l|cccc}
\hline Species & Height & \multicolumn{3}{|c}{ Variables measured } \\
\cline { 3 - 5 } & $(\mathbf{m m})$ & Lesion length (mm) & Dieback (\%) & Re-sprout (mm) \\
$\boldsymbol{P}$. patula & $139.92^{\mathrm{A}}$ & $21.04^{\mathrm{A}}$ & $16.39^{\mathrm{A}}$ & $18.99^{\mathrm{BC}}$ \\
$\boldsymbol{P}$. tecHE & $107.37^{\mathrm{C}}$ & $8.63^{\mathrm{B}}$ & $8.93^{\mathrm{B}}$ & $22.00^{\mathrm{BA}}$ \\
$\boldsymbol{P}$. elliottii & $109.66^{\mathrm{C}}$ & $5.91^{\mathrm{C}}$ & $6.02^{\mathrm{C}}$ & $17.27^{\mathrm{C}}$ \\
$\boldsymbol{P}$. taeda & $123.33^{\mathrm{B}}$ & $4.95^{\mathrm{C}}$ & $4.22^{\mathrm{D}}$ & $15.87^{\mathrm{C}}$ \\
$\boldsymbol{P} . \boldsymbol{m a x i m i n o i}$ & $95.68^{\mathrm{D}}$ & $3.19^{\mathrm{D}}$ & $3.84^{\mathrm{DE}}$ & $25.44^{\mathrm{A}}$ \\
$\boldsymbol{P}$. tecLE & $136.47^{\mathrm{A}}$ & $2.96^{\mathrm{D}}$ & $2.19^{\mathrm{E}}$ & $24.11^{\mathrm{A}}$ \\
\hline
\end{tabular}

Species that share the same letter (Duncan grouping) are not significantly different. 
Table 6. Mean values of the variables measured for the species tested as controls, and $P$. maximinoi provenances (represented by at least 4 families).

\begin{tabular}{|c|c|c|c|c|c|}
\hline Provenance & $\begin{array}{l}\text { Country } \\
\text { of origin }\end{array}$ & Families & $\begin{array}{l}\text { Lesion length } \\
(\mathrm{mm})\end{array}$ & $\begin{array}{c}\text { Dieback } \\
(\%)\end{array}$ & $\begin{array}{l}\text { Re-sprout } \\
\text { (mm) }\end{array}$ \\
\hline P. patula (control) & & Mix & $21.04^{A}$ & $16.39^{\mathrm{A}}$ & $18.99^{\mathrm{FE}}$ \\
\hline P. tecunumanii - high (control) & & Mix & $8.63^{\mathrm{B}}$ & $8.93^{\mathrm{B}}$ & $22.00^{\mathrm{DEC}}$ \\
\hline P. elliottii (control) & & Mix & $5.91^{\mathrm{C}}$ & $6.02^{\mathrm{C}}$ & $17.27^{\mathrm{F}}$ \\
\hline P. taeda (control) & & Mix & $4.95^{\mathrm{DC}}$ & $4.22^{\mathrm{DFE}}$ & $15.87^{\mathrm{F}}$ \\
\hline Altamirano & Mexico & 4 & $3.64^{\mathrm{FE}}$ & $4.00^{\mathrm{DFE}}$ & $21.64^{\mathrm{DE}}$ \\
\hline San Juan Sacateqequez & Guatemala & 18 & $3.32^{\mathrm{FE}}$ & $4.07^{\mathrm{DFE}}$ & $25.96^{\mathrm{BAC}}$ \\
\hline San Jerónimo Chiapas & Mexico & 13 & $3.28^{\mathrm{FE}}$ & $3.28^{\mathrm{FE}}$ & $25.16^{\mathrm{BDAC}}$ \\
\hline El Portillo & Honduras & 16 & $3.21^{\mathrm{F}}$ & $3.21^{\mathrm{F}}$ & $24.80^{\mathrm{BDAC}}$ \\
\hline Dulce Nombre de Copan & Honduras & 8 & $3.20^{\mathrm{F}}$ & $3.20^{\mathrm{F}}$ & $24.78^{\mathrm{BDAC}}$ \\
\hline San Jerónimo Baja Verapaz & Guatemala & 19 & $3.17^{\mathrm{F}}$ & $3.91^{\mathrm{DFE}}$ & $25.02^{\mathrm{BDAC}}$ \\
\hline Coban & Mexico & 13 & $3.06^{\mathrm{F}}$ & $3.87^{\mathrm{DFE}}$ & $26.73^{\mathrm{BA}}$ \\
\hline Tatumbla & Honduras & 6 & $2.98^{\mathrm{F}}$ & $3.92^{\mathrm{DFE}}$ & $24.98^{\mathrm{BDAC}}$ \\
\hline Marcala & Honduras & 4 & $2.91^{\mathrm{FG}}$ & $3.35^{\mathrm{GFE}}$ & $27.39^{\mathrm{BA}}$ \\
\hline P. tecunumanii - low (control) & & Mix & $2.70^{\mathrm{FG}}$ & $2.19^{\mathrm{G}}$ & $24.11^{\mathrm{BDAC}}$ \\
\hline
\end{tabular}

Provenances that share the same letter (Duncan grouping) are not significantly different.

Table 7. Comparison of the responses to inoculation with $F$. circinatum on $P$. elliottii with those on $P$. patula and $P$. taeda based on lesion length, die-back and the ability of plants to re-sprout.

\begin{tabular}{l|cccc}
\hline Species inoculated & Height & \multicolumn{3}{|c}{ Disease characteristics } \\
\cline { 3 - 5 } & $\mathbf{( m m )}$ & Lesion length (mm) & Dieback (\%) & Re-sprout (mm) \\
P. patula (control) & 148.34 & $23.7^{\mathrm{A}}$ & $9.46^{\mathrm{A}}$ & $10.40^{\mathrm{B}}$ \\
P. elliottii & 124.24 & $5.3^{\mathrm{B}}$ & $2.44^{\mathrm{B}}$ & $24.19^{\mathrm{A}}$ \\
P. taeda (control) & 136.67 & $4.2^{\mathrm{B}}$ & $1.53^{\mathrm{C}}$ & $9.97^{\mathrm{B}}$ \\
\hline
\end{tabular}


Table 8. Comparison of the responses of inoculation with $F$. circinatum on $P$. pseudostrobus with those on $P$. patula, $P$. elliottii and $P$. taeda based on lesion length, die-back and the ability of plants to re-sprout.

\begin{tabular}{l|cccc}
\hline Variety & Height & \multicolumn{3}{|c}{ Variables measured } \\
\cline { 3 - 5 } & $\mathbf{( m m )}$ & Lesion length (mm) & Dieback (\%) & Re-sprout (mm) \\
P. patula & 136.67 & $24.6^{\mathrm{A}}$ & $21.7^{\mathrm{A}}$ & $10.6^{\mathrm{A}}$ \\
P. elliottii & 124.24 & $10.8^{\mathrm{B}}$ & $10.2^{\mathrm{B}}$ & $42.6^{\mathrm{B}}$ \\
P. taeda & 148.34 & $7.1^{\mathrm{C}}$ & $5.8^{\mathrm{C}}$ & $17.3^{\mathrm{C}}$ \\
P. pseudostrobus & 147.68 & $3.7^{\mathrm{D}}$ & $2.6^{\mathrm{D}}$ & $21.3^{\mathrm{C}}$ \\
\hline
\end{tabular}

Species that share the same letter (Duncan grouping) are not significantly different.

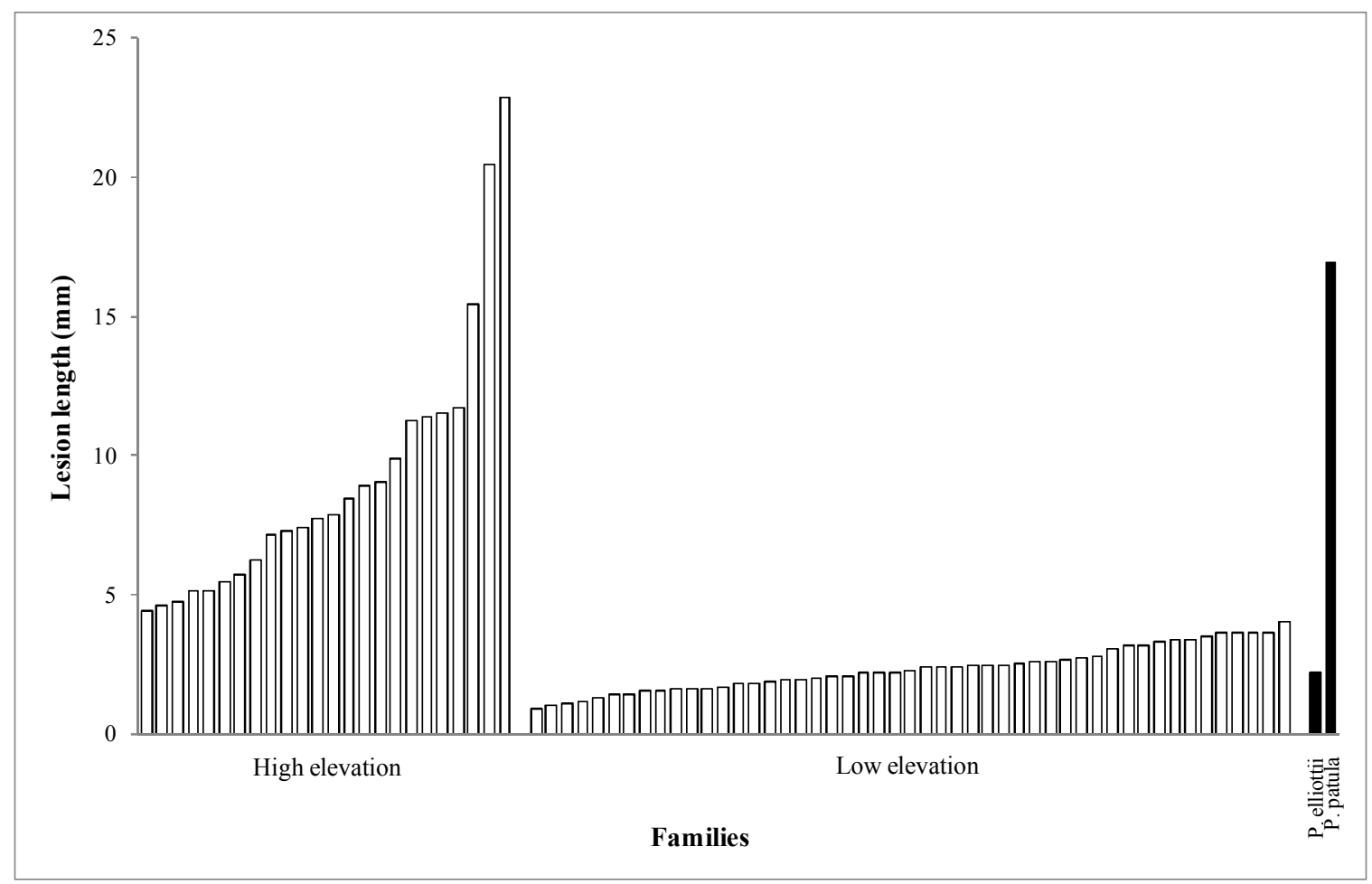

Fig. 1. Mean lesion length (corrected for height) for all $P$. tecunumanii families screened for tolerance to $F$. circinatum compared to the controls ( $P$. elliottii and $P$. patula). Within ecotype, treatments are ranked from most to least tolerant. Narrow-sense heritability (Dieters et al., 1995) was calculated at 0.59 for the high elevation ecotype and 0.01 for the low elevation ecotype. 


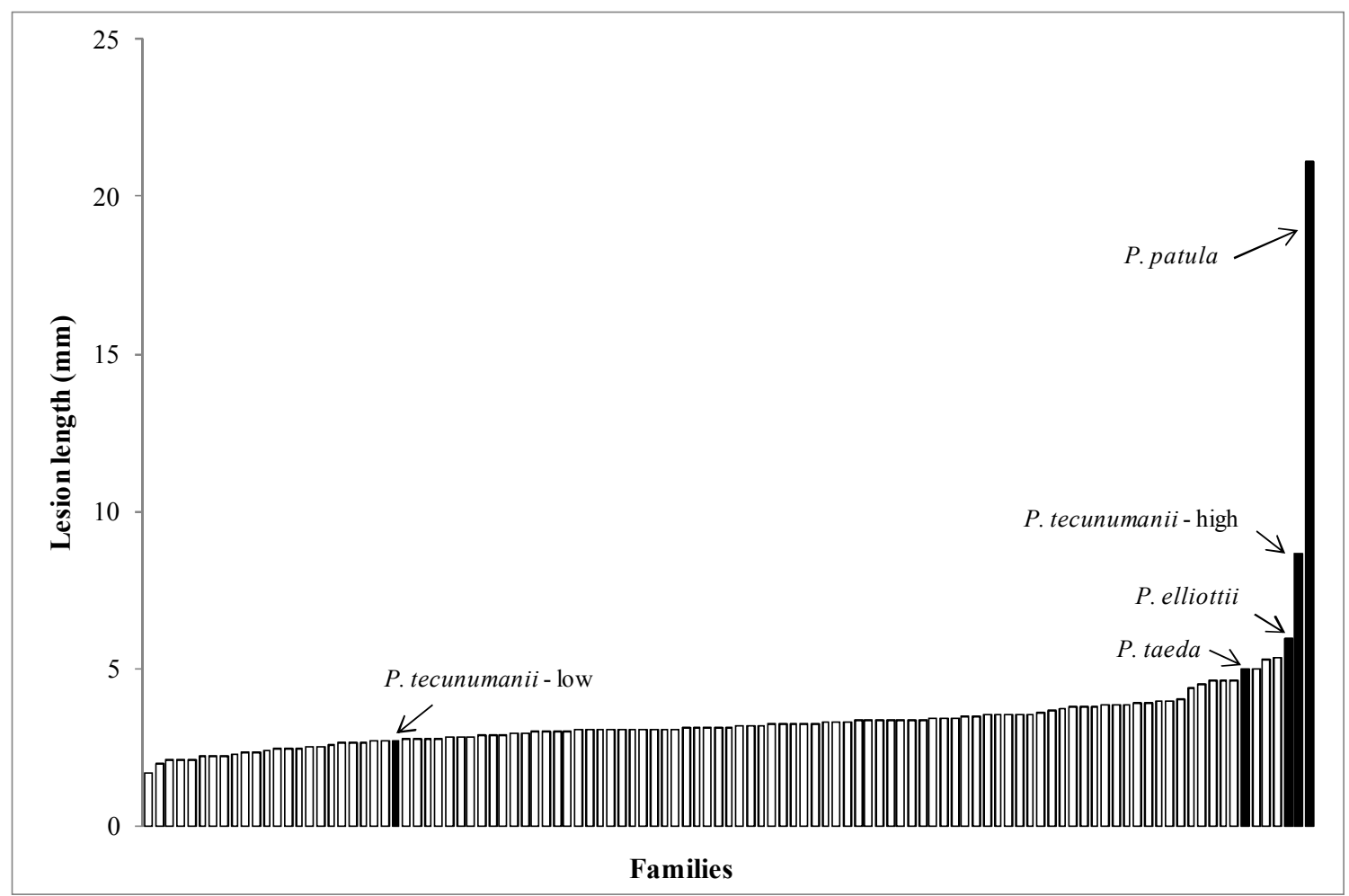

Fig. 2 Mean lesion length (corrected for height) for all $P$. maximinoi families screened compared to the controls. Treatments are ranked from most to least tolerant. Narrow-sense heritability (Dieters et al., 1995) was calculated at 0.014 . 


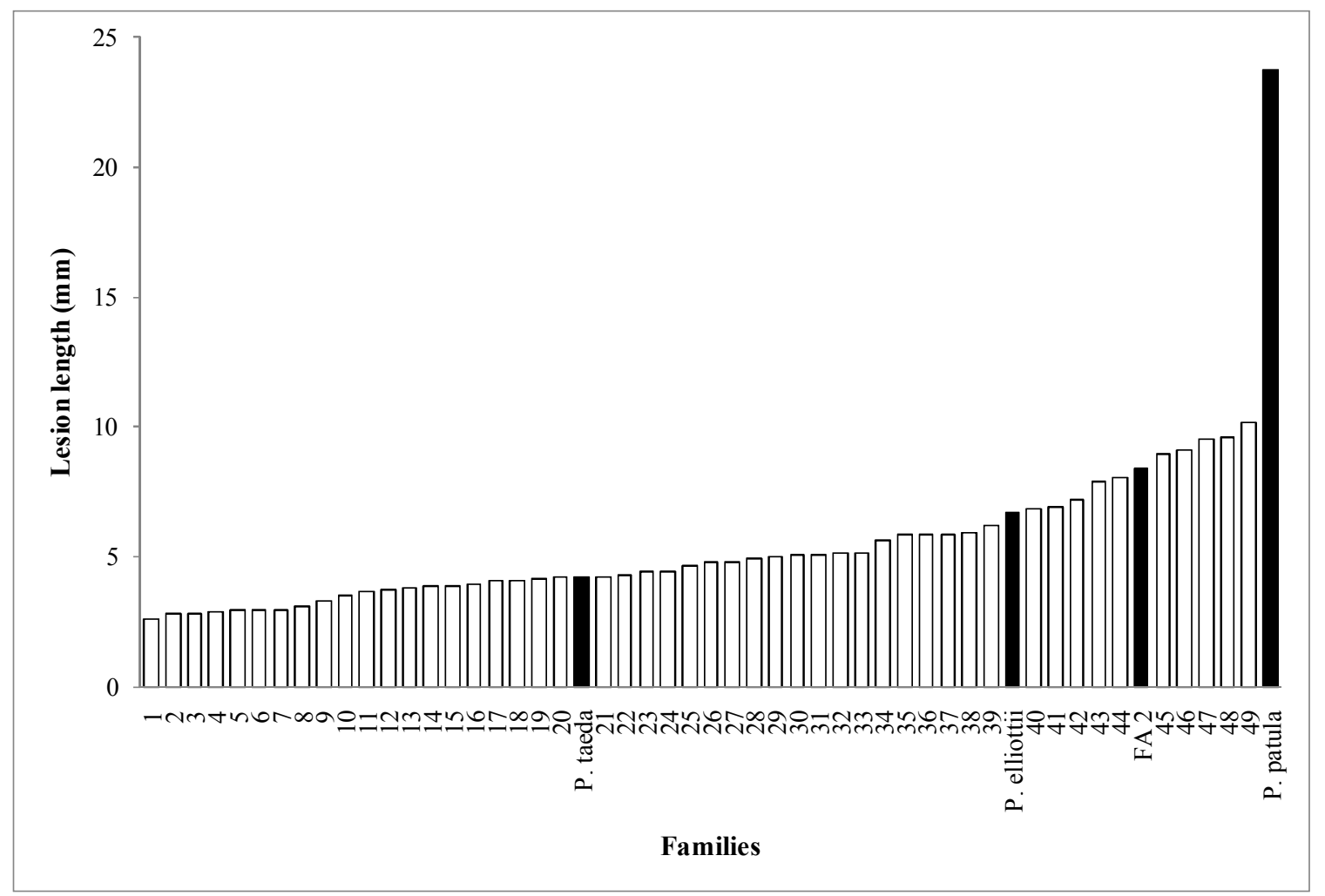

Fig. 3 Mean lesion length (corrected for height) for all $P$. elliottii families inoculated with $F$. circinatum compared to the $P$. patula and $P$. taeda controls and the susceptible $P$. elliottii control (FA2). Treatments are ranked from most to least tolerant. Narrow-sense heritability (Dieters et al., 1995) was calculated as 0.22 . 


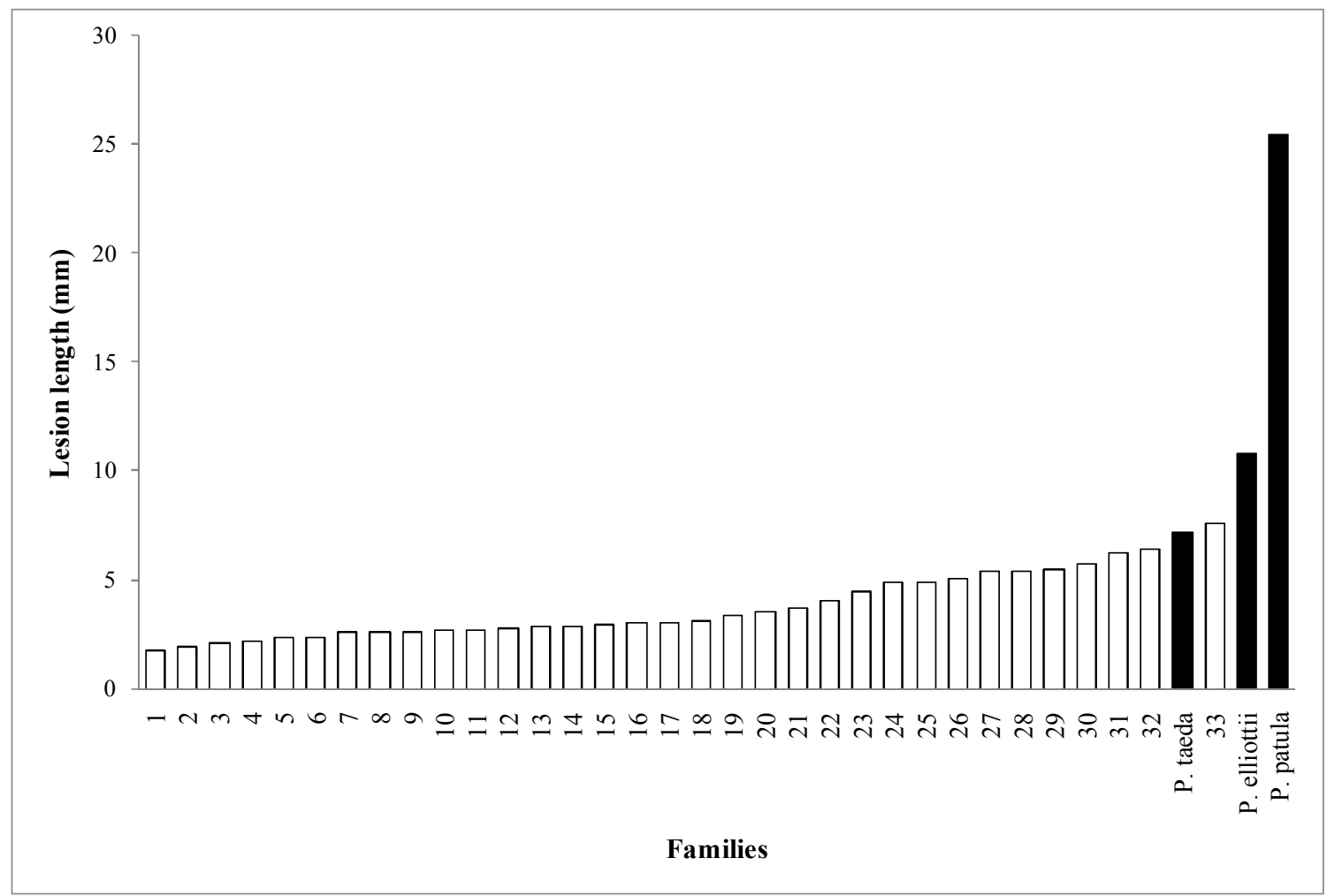

Fig. 4 Mean lesion length (corrected for height) for all $P$. pseudostrobus families screened compared to the controls. Treatments are ranked from most to least tolerant. Narrow-sense heritability (Dieters et al., 1995) was calculated at 0.06 . 